\title{
Fault model of the 12th century southwestern Hokkaido earthquake estimated from tsunami deposit distributions
}

\author{
Kei loki ${ }^{*} \mathbb{D}$, Yuichiro Tanioka ${ }^{2}$, Gentaro Kawakami ${ }^{3}$, Yoshihiro Kase ${ }^{3}$, Kenji Nishina ${ }^{3}$, Wataru Hirose ${ }^{3}$, \\ Kei'ichi Hayashi ${ }^{3}$ and Ryo Takahashi ${ }^{3}$
}

\begin{abstract}
Tsunami deposits were collected along the coast of southwestern Hokkaido and Okushiri Island, northern Japan. The distribution of these deposits suggested that large earthquakes and tsunamis have repeatedly occurred off southwestern Hokkaido. Along the southern coast of Okushiri Island, five tsunami sand/gravel layers have been deposited during the last 3000 years. The latest was deposited by the 1741 Oshima-Oshima landslide tsunami and the second by the 12th century tsunami. The later tsunami was probably generated by a large earthquake because submarine seismo-turbidites with similar age exist in the region and a large inland landslide had occurred in Okushiri Island in approximately the 12th century. The ages of paleo-tsunami events prior to the 12th century are 1.5-1.6, 2.4-2.6, 2.8-3.1 ka. In this study, a fault model of the 12th century earthquake was estimated by comparing tsunami deposit distributions and calculated tsunami inundation areas at five sites in Okushiri Island and Hiyama region. Fault model F17, a submarine active fault in the Japan Sea near Oshima-Oshima, is a probable source for this tsunami. Numerical simulation of the tsunami was performed based on fault model F17; we modified the fault parameters (length and slip amount) from the original model to explain tsunami deposit distributions. A shorter length of $104 \mathrm{~km}$ and a larger slip amount of $18 \mathrm{~m}$ were appropriate for the fault model on the basis of parametric studies. The seismic moment of the earthquake was calculated to be $9.95 \times 10^{20} \mathrm{Nm}\left(M_{w} 7.9\right)$ assuming a rigidity of $3.43 \times 10^{10} \mathrm{~N} / \mathrm{m}^{2}$. The estimated fault model is located between the focal regions of the 1993 Hokkaido Nansei-oki earthquake and the 1983 Japan Sea earthquake.
\end{abstract}

Keywords: Tsunami deposit, Tsunami inundation, Great earthquake, Hokkaido, Japan Sea

\section{Introduction}

Earthquakes with magnitude larger than $M_{w} 7.5$ have repeatedly occurred from off northern Hokkaido to Tohoku region in the Japan Sea (Katsumata et al. 2004). Large tsunamis have been generated by these earthquakes and damaged the coastal areas in Hokkaido and Tohoku region (Watanabe 1998). Earthquake occurrence and tsunami generation are related to active faults along the eastern margin of the Japan Sea (Okamura et al.

\footnotetext{
*Correspondence: kei-ioki@aist.go.jp

${ }^{1}$ Geological Survey of Japan, National Institute of Advanced Industrial

Science and Technology, 1-1-1 Higashi, Tsukuba 305-8567, Japan

Full list of author information is available at the end of the article
}

1998). Distribution of active faults in Japan Sea is also studied (Okamura 2019).

The 1993 Hokkaido Nansei-oki earthquake (hereafter the 1993 earthquake) occurred near Okushiri Island, southwestern Hokkaido. A large tsunami was generated by the 1993 earthquake (Shuto 1995), and more than 200 people were killed by the tsunami (Watanabe 1998). Tsunami heights of more than $20 \mathrm{~m}$ were recorded along the western coast of Okushiri Island (Tsuji et al. 1993; Kawakami et al. 2017a). Tsunami deposits of the 1993 earthquake are widely distributed along the west coast of Oshima Peninsula, southwestern Hokkaido (Nishimura and Miyaji 1995). In a previous study, a source area of $150 \times 70 \mathrm{~km}^{2}$ was estimated by means of an inverse tsunami travel time diagram for the 1993 earthquake (Hatori 
1994). A fault model of the 1993 earthquake was estimated using seismic wave, tsunami, and geodetic data (Satake and Tanioka 1995; Tanioka et al. 1995). A seismic moment of $4.9 \times 10^{20} \mathrm{Nm}\left(\mathrm{M}_{\mathrm{w}} 7.7\right)$ was also calculated from the estimated slip distribution of the 1993 earthquake.

The 1983 Japan Sea earthquake (hereafter the 1983 earthquake) also occurred off the Tohoku region in the Japan Sea. A large tsunami was generated by the earthquake (Shuto et al. 1995), and more than 100 people were killed by the tsunami in Hokkaido, Aomori, and Akita Prefectures in the Tohoku region (Watanabe 1998). Tsunami heights of more than $10 \mathrm{~m}$ were recorded along the coast of Akita Prefecture in the Tohoku region (Hata et al. 1995; Kawakami et al. 2017a). A tsunami source area of $140 \times 90 \mathrm{~km}^{2}$ was estimated by means of an inverse refraction diagram for the 1983 earthquake (Hatori 1983). A mechanism of the 1983 earthquake was estimated from surface waves and tsunamis (Satake 1985). A seismic moment of the 1983 earthquake of $4.2 \times 10^{20} \mathrm{Nm}$ $\left(\mathrm{M}_{\mathrm{w}}\right.$ 7.7) was also estimated from tsunami waveform inversion (Satake 1989).

Tsunami deposits were collected along the coast of the Japan Sea in Hokkaido by recent studies (Kase et al.
2016; Kawakami et al. 2017b) (Fig. 1). Distributions of these deposits suggest that large earthquakes and tsunamis have repeatedly occurred off southwestern Hokkaido. These deposits are distributed farther inland and at higher elevations than the tsunami inundation area of the 1993 Hokkaido Nansei-oki earthquake. The age of the widely distribution tsunami deposits is older than the 1741 Oshima-Oshima tsunami (Satake 2007) and has been estimated to be approximately 900 years old. The source of this tsunami is considered to be near that of the 1741 Oshima-Oshima tsunami (Kawakami et al. 2017a; Ioki et al. 2019). The 12th century tsunami has a high possibility to be generated by an earthquake because of the existence of a seismogenic turbidite bed (Nakajima and Kanai 2000) and a large subaerial landslide following the earthquake (Amemiya et al. 1998; Kawakami et al. 2017b) dated at approximately the 12th century and the existence of submarine active faults in the Japan Sea (Okamura et al. 2005). The other reason of that the 12th century tsunami has been generated by an earthquake is tsunamis have been repeatedly generated five times over 3000 years based on the tsunami deposit survey (Kawakami et al. 2017b). Fault models of expected earthquakes in this region have been reported

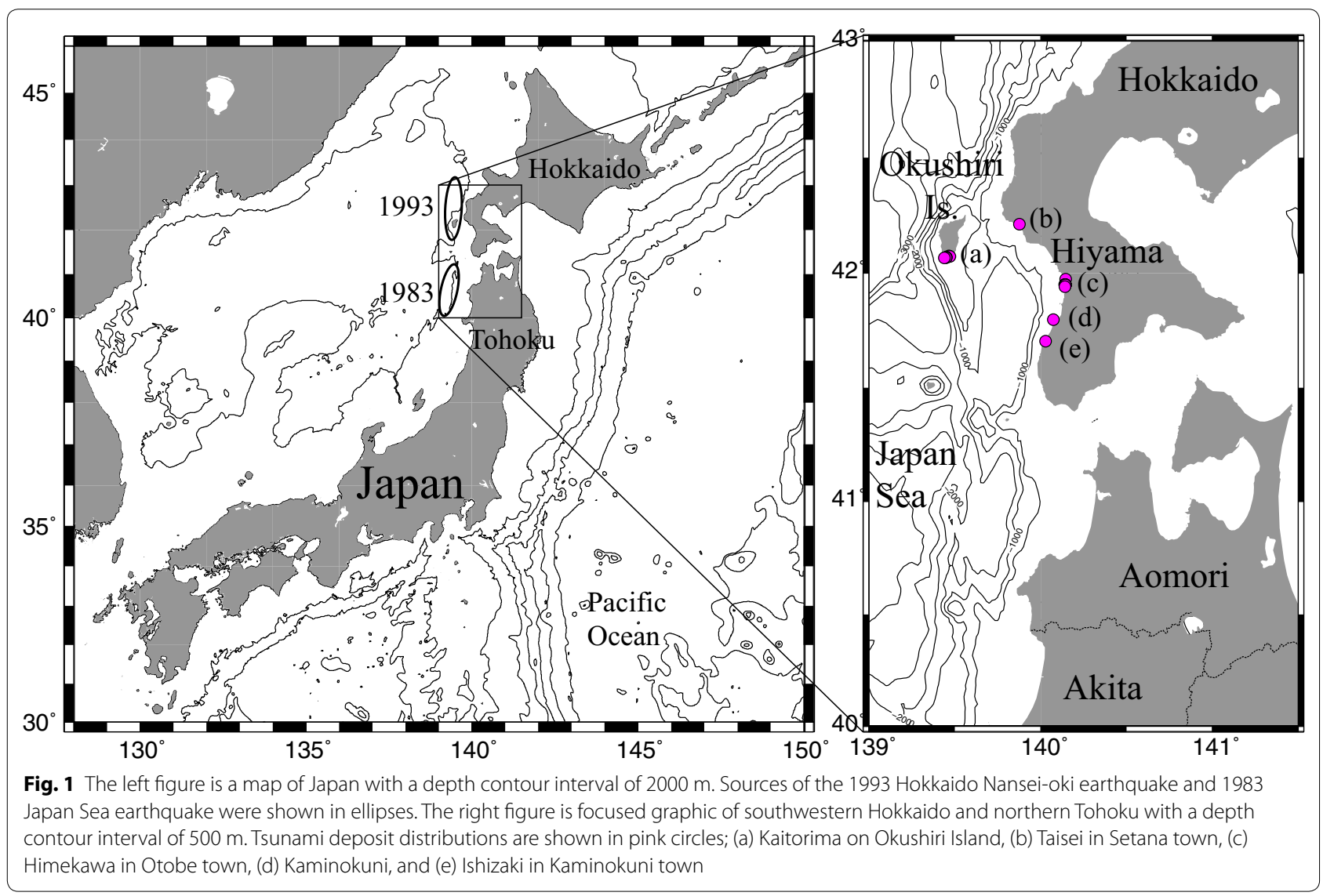


by the Investigative Commission Related to Great Earthquakes in the Japan Sea (2014) and the Hokkaido Disaster Management Council (2017). In this study, we estimated a fault model of the 12th century earthquake to explain the tsunami deposit distributions (Fig. 2). Comparing the estimated fault model and the source models of the 1993 Hokkaido Nansei-oki and 1983 Japan Sea earthquakes, the rupture processes of earthquakes in the Japan Sea off Hokkaido, Japan, were discussed.

\section{Previous studies}

\section{Tsunami deposits}

Recently, tsunami deposits have been found at Okushiri Island and southwestern Hokkaido along the Japan Sea coast (Kase et al. 2016; Kawakami et al. 2017b). Along the southern coast of Okushiri Island, five tsunami sand/gravel layers have been deposited during the last 3000 years. The latest layer was deposited by the 1741 Oshima-Oshima tsunami, and the second layer was deposited by the 12th century tsunami. The ages of paleo-tsunami events prior to the 12th century are 1.5-1.6, 2.4-2.6, 2.8-3.1 ka. The long-term recurrences of large tsunamis are only clear in deposits from
Okushiri Island. The recurrence interval of tsunami is 200-1100 years (500 years on average). The tsunami deposit ages were estimated using tephrochronology and the accelerator mass spectrometry ${ }^{14} \mathrm{C}$ age of peat. Tsunami sand sheets from the 12th century have been found between the Komagatake-d (Ko-d, 1640 AD; Tokui 1989) tephra layer and Baitoushan-Tomakomai (B-Tm, ca $1 \mathrm{ka}$; Yin et al. 2012) tephra layer in Okushiri Island. Tsunami deposits from the 12th century tsunami have also been found along the Okushiri and Hiyama coasts (Kawakami et al. 2017b). The 12th century tsunami has no historical record because the written history for the region was started in the late 17th century in southwestern Hokkaido.

Based on Geological Survey of Hokkaido (2015), Kase et al. (2016), and Kawakami et al. (2017b), tsunami deposit distributions are summarized in the following. At Kaitorima on Okushiri Island [(a) in Figs. 1 and $3]$, tsunami gravels were found at a sea cliff section on a Holocene marine terrace at the present elevation of $8 \mathrm{~m}$. Along the Wasabiyachigawa River lowland on Okushiri Island, tsunami sand beds were found on the western bank of the river at the present elevation of $5 \mathrm{~m}$ and

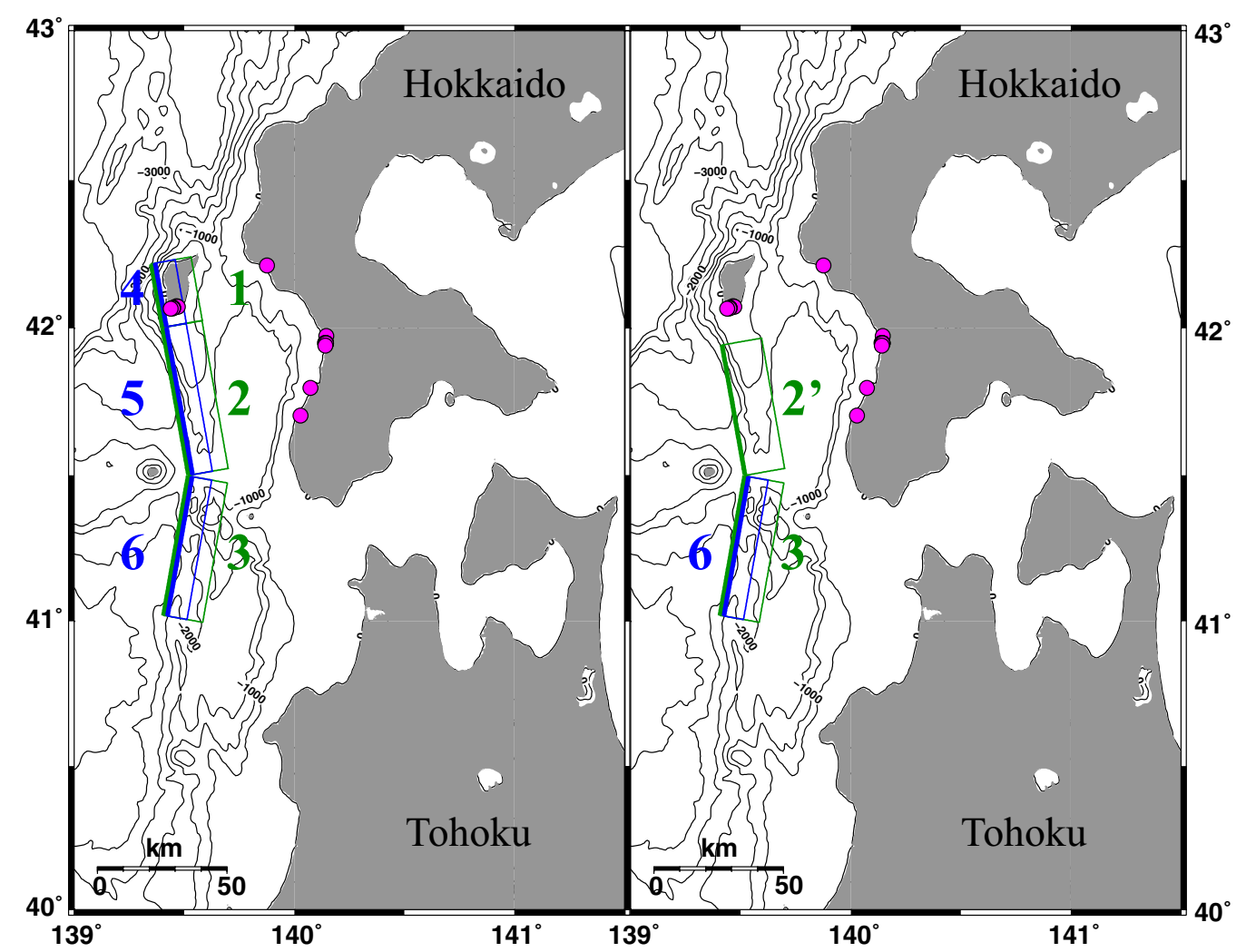

Fig. 2 Locations of subfaults are shown with a depth contour interval of $500 \mathrm{~m}$. The left figure is fault model F17 used to calculate the anticipated inundation of the tsunami in the Japan Sea by the Hokkaido Disaster Management Council (2017). The right figure is the fault model estimated in this study. Detailed fault model parameters are provided in Tables 1 and 2. Tsunami deposit distributions are shown in pink circles 
$400 \mathrm{~m}$ distant from the present coastline. At Hatsumatsumae on Okushiri Island, possible tsunami gravels present in Aonae coastal sand dunes up to $10 \mathrm{~m}$. Behind of the Aonae sand dune, tsunami sand beds were found in peat along a branch of the Akagawa River. At Taisei in Setana town [(b) in Figs. 1 and 3], tsunami sandy deposits were identified in the narrow coastal plain at a present elevation of $4 \mathrm{~m}$. At Himekawa in Otobe town [(c) in Figs. 1 and 3], tsunami sand beds were identified along the northern bank of the river $1 \mathrm{~km}$ inland from the present coastline at an elevation of $3 \mathrm{~m}$. At Gorinzawa in Esashi town, tsunami sand beds were identified in peat 500-900 $\mathrm{m}$ inland from the present coastline at an elevation of 6-7 m. At Kaminokuni in Kaminokuni town [(d) in Figs. 1 and 3], possible tsunami gravels were found on a gentle talus slope of $7 \mathrm{~m}$ elevation located at the front of a marine terrace. At Ishizaki in Kaminokuni town [(e) in Figs. 1 and 3], a medium-grained sand layer of possible tsunami origin was newly identified by auger survey in this study, which present in humic mud at a horizon $20 \mathrm{~cm}$ below Ko-d tephra layer $(80 \mathrm{~cm}$ depth). The site is located in the alluvial plain of the Ishizaki River at a present elevation of $5 \mathrm{~m}$ and ca. $500 \mathrm{~m}$ inland from the present coastline.

\section{Fault model}

The calculated tsunami inundation map was established along the coast of Japan Sea (Investigative Commission Related to Great Earthquakes in the Japan Sea 2014). For estimation of fault models, first, occurrence records of past earthquakes and tsunamis in the Japan Sea were studied. Tsunamis with damage were generated in 10-20 year interval in the Japan Sea. Historical records and surveyed data of tsunami heights and deposits were also studied along the coast of the Japan Sea. Tsunami deposits distributions of more than 30 were collected along the coast of Japan Sea. Second, location, length, and strike of submarine active faults having a tsunamigenic potential in the Japan Sea were established by seismic reflection survey (e.g., Okano et al. 1995; Okamura et al. 2005). The dip was estimated from the reflecting plain of the seismic reflection survey. The rake of the fault models was established from tectonic stress fields in and around Japan (Terakawa and Matsu'ura 2010). The depths of the upper edge of the fault models were set as the average depth of the water plus $1 \mathrm{~km}$ for the submarine active faults. The depths of the bottom edge of the fault models were fixed based on the estimated seismogenic zone of the crustal structures in the Japan Sea (Sato et al. 2014). The slip amount of the fault models was established from scaling relation in relation to seismic moment and area, length, and slip amount of fault models in previous studies (Murotani et al. 2010; Tajima et al. 2013). Furthermore, a large slip amount area in the shallow part of the fault models was set. The length and width of a large slip amount area were smaller than those of fault models.

Based on fault models described above, fault models were re-estimated by the Hokkaido Disaster Management Council (2017) for re-examination of calculated tsunami inundation along the coast of Hokkaido. One of the re-estimated points is that the length of the large slip amount area was extended to the length of fault models.

\section{Method \\ Fault model}

Tsunami deposits of the 12th century tsunami and the 1741 Oshima-Oshima tsunami were found at many sites on Okushiri Island and in the Hiyama region, southwestern part of Hokkaido. Tsunami deposit distributions of the 12th century cannot be explained by fault models for the 1993 and 1983 earthquake. From tsunami deposit distributions, tsunami source of the 12th century is considered to be located near the source of the 1741 Oshima-Oshima sector collapse.

Fault model F17 of the Hokkaido Disaster Management Council (2017) was selected as the basis for this study because its location is near Oshima-Oshima and the computed tsunami heights in the Hiyama region were the largest among those from the other models. Location and fault model parameters of fault model F17 are shown in Fig. 2 and Table 1.

\section{Bathymetry and topography}

Bathymetry was based on M7000 series bathymetric digital data published by the Japan Hydrographic Association, J-EGG500 JODC-Expert Grid data for Geography published by the Japan Oceanographic Data Center, and JTOPO30 published by the Marine Information Research Center, Japan Hydrographic Association. Topography was based on digital elevation model with a mesh size of $10 \mathrm{~m}$ published by the Geospatial Information Authority of Japan. We created the bathymetric and topographic grid by interpolating these bathymetric and topographic data. A bathymetric and topographic grid with a spatial resolution of 3 arc-seconds was used for computing the tsunami within these coordinates $138.20^{\circ}-142^{\circ} \mathrm{E}$, $40^{\circ}-43.20^{\circ} \mathrm{N}$. In this area, artificial structures such as sea walls and harbors were removed referencing to the old topographic maps published in the 19th century and early 20th century. Fortunately, the anthropogenic modifications and developments in the area were limited. The local bathymetric and topographic data of a grid interval of $23 \mathrm{~m}$ (approximately 1 arc-second) were used in computing the small area of tsunami inundation shown in 


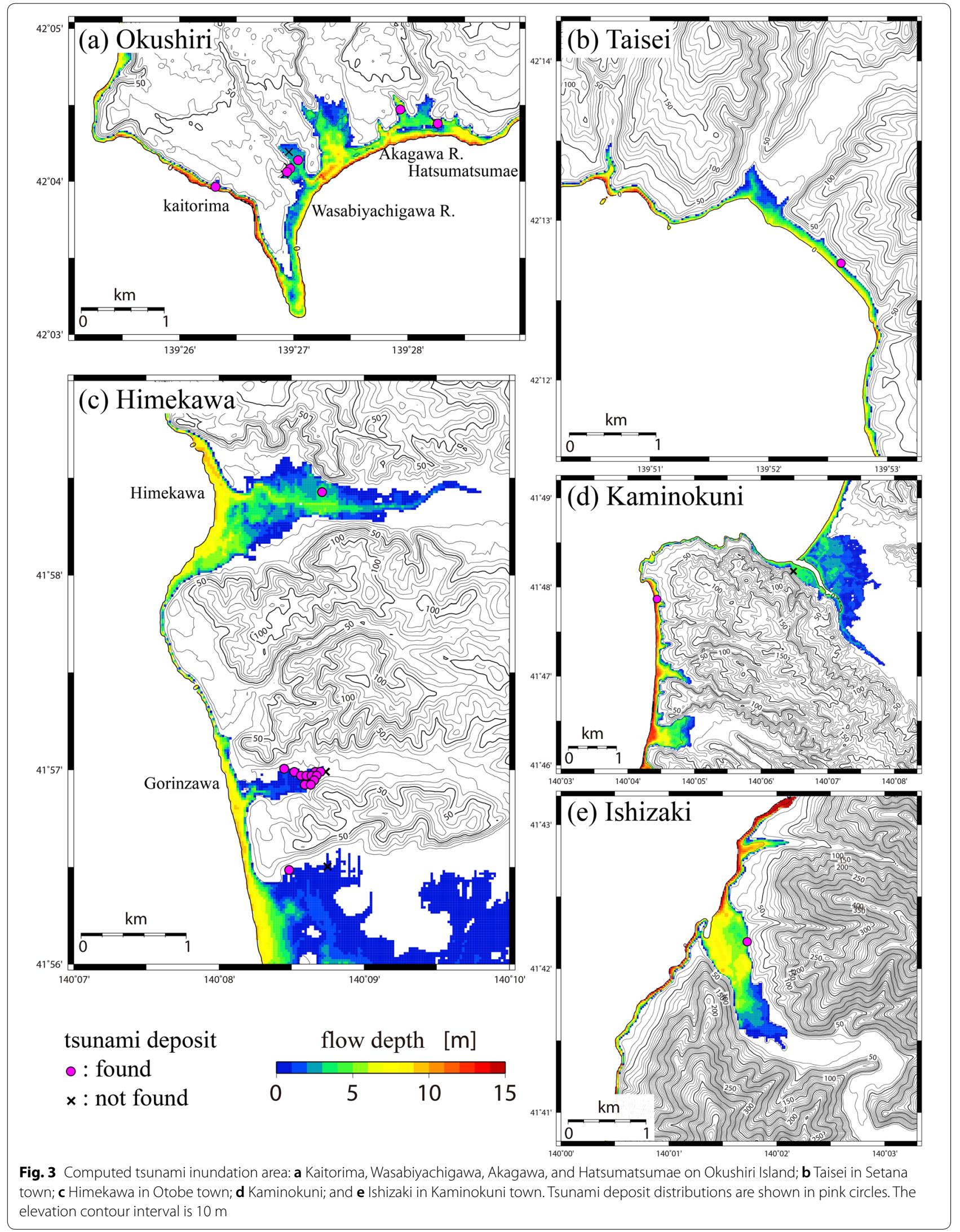


Table 1 Subfault model parameters of fault model F17 by the Hokkaido Disaster Management Council (2017)

\begin{tabular}{llllllllll}
\hline $\begin{array}{l}\text { Subfault } \\
\text { number }\end{array}$ & Length $(\mathbf{k m})$ & Width $(\mathbf{k m})$ & Strike $\left(^{\left.{ }^{\circ}\right)}\right.$ & Dip $\left(^{\circ}\right)$ & Rake $\left(^{\circ}\right)$ & Depth $(\mathbf{k m})$ & Slip $(\mathbf{m})$ & Longitude $\left(^{\circ}\right)$ & Latitude $\left(^{\circ}\right)$ \\
\hline 1 & 24 & 22 & 350 & 45 & 96 & 2.8 & 4.8 & 139.400994 & 42.00258 \\
2 & 57 & 22 & 350 & 45 & 96 & 2.8 & 4.4 & 139.51981 & 41.49980 \\
3 & 54 & 22 & 10 & 45 & 106 & 2.8 & 4.6 & 139.40581 & 41.02010 \\
4 & 24 & 11 & 350 & 45 & 96 & 4.3 & 7.2 & 139.41905 & 42.00498 \\
5 & 57 & 11 & 350 & 45 & 96 & 4.3 & 7.7 & 139.53778 & 41.50218 \\
6 & 54 & 11 & 10 & 45 & 106 & 4.3 & 7.4 & 139.42365 & 41.01771 \\
\hline
\end{tabular}

Fig. 3. At the survey sites of tsunami deposits located in alluvial plains, the topographic elevations were replaced by the elevations of the base of the 12th century tsunami layer confirmed by soil auger survey at stations arranged ca $50 \mathrm{~m}$ interval grid (40 stations in the alluvial plain $\left(0.08 \mathrm{~km}^{2}\right)$ along the Wasabiyachigawa River; 31 stations $\left(0.04 \mathrm{~km}^{2}\right)$ along the branch of the Akagawa River; 76 stations $\left(0.15 \mathrm{~km}^{2}\right)$ along the right bank of the Himekawa River; and 80 stations $\left(0.14 \mathrm{~km}^{2}\right)$ along the Gorinzawa). At the station where the tsunami deposits are not recognized, the horizon of 12 th century was estimated by the interval of Ko-d and B-Tm tephra layers. As a result, elevations during the 12 th century were $50-150 \mathrm{~cm}$ lower than those of present.

\section{Numerical simulation}

First, ocean bottom deformation was computed using Okada's formula (Okada 1985) with a base fault model. In this study, sea surface deformation was assumed to be the same as the ocean bottom deformation. Then, to compute tsunami heights in the large computational area, linear shallow water equations were solved using the staggered leap-flog method (Satake 1995). To calculate tsunami inundations in the small computational areas, nonlinear shallow water equations were solved using the moving boundary condition (Imamura 1996; Goto et al. 1997). Manning's roughness coefficient of $0.025 \mathrm{~m}^{-1 / 3} \mathrm{~s}$ was set as the bottom friction term. The bathymetry in the tsunami calculation was displaced in accordance with the coseismic crustal deformation. A duration to rupture of $1 \mathrm{~s}$ was assumed. To satisfy the Courant-FriedrichsLewy (CFL) stability condition, a time step of $0.05 \mathrm{~s}$ was established. The output time of the data was set for every $1 \mathrm{~s}$.

To fit the computed tsunami inundation areas with the tsunami deposit distributions of the 12th century tsunami, numerical simulation was repeatedly performed changing the fault model. By parameter study of the location, length, and slip amount, the best fault model was estimated to explain the tsunami deposit distributions from the 12th century event.

\section{Results}

Tsunami inundation computation was performed in five areas of Okushiri Island, Taisei, Himekawa, Kaminokuni, and Ishizaki. Computed tsunami inundation areas were compared to tsunami deposit distributions. As a result, subfault 1 and subfault 4 in the north part of fault model F17 were removed because the computed tsunami inundation area was too large compared to tsunami deposit distributions on Okushiri Island. Another reason is that the computed coseismic deformation was too large on Okushiri Island. Uplift of 4-5 m was computed because subfault 1 and subfault 4 are directly below Okushiri Island; however, no stratigraphic record of such a large coseismic uplift has been recognized in peat above and below the tsunami sand bed from the 12th century on Okushiri Island.

The slip amount of subfault 2 and subfault 5 was enlarged because the computed tsunami inundation area was too small compared to the tsunami deposit distributions at Otobe town in the Hiyama region. A slip amount of $18 \mathrm{~m}$ on subfault $2^{\prime}$ was estimated to produce a computed tsunami inundation area that matches the tsunami deposit distribution at Otobe town (Fig. 3c). The length of $7 \mathrm{~km}$ for subfault 2 should be reduced to produce a computed tsunami inundation area that matches the tsunami deposit distribution on Okushiri Island. A length of $50 \mathrm{~km}$ for subfault $2^{\prime}$ was estimated to fit the computed tsunami inundation area and tsunami deposit distributions on Okushiri Island (Fig. 3a).

These subfaults can explain the tsunami deposit distributions in other tsunami inundation areas (Fig. 3b, $\mathrm{d}$ and e). The location of the estimated fault model in this study is shown in Fig. 2, and the fault model parameters are shown in Table 2. A seismic moment of $9.95 \times 10^{20} \mathrm{Nm}$ $\left(M_{w} 7.9\right)$ was calculated from the estimated fault model assuming a rigidity of $3.43 \times 10^{10} \mathrm{~N} / \mathrm{m}^{2}$. 
Table 2 Subfault model parameters of modified fault model F17 in this study

\begin{tabular}{llllllllll}
\hline $\begin{array}{l}\text { Subfault } \\
\text { number }\end{array}$ & Length $(\mathbf{k m})$ & Width $(\mathbf{k m})$ & Strike $\left(^{\circ}\right)$ & Dip $\left(^{\circ}\right)$ & Rake $\left({ }^{\circ}\right)$ & Depth $(\mathbf{k m})$ & Slip $(\mathbf{m})$ & Longitude $\left(^{\circ}\right)$ & Latitude $\left({ }^{\circ}\right)$ \\
\hline $2^{\prime}$ & 50 & 22 & 350 & 45 & 96 & 2.8 & 18 & 139.51981 & 41.49980 \\
3 & 54 & 22 & 10 & 45 & 106 & 2.8 & 4.6 & 139.40581 & 41.02010 \\
6 & 54 & 11 & 10 & 45 & 106 & 4.3 & 7.4 & 139.42365 & 41.01771 \\
\hline
\end{tabular}

\section{Discussion}

We modified the parameters of length and slip amount in the fault model; other parameters were not changed from those values of previous studies regarding the existence of submarine active faults, seismic reflection, crustal structures, and so on.

In a previous study, tsunami deposits have been deposited with at least $1 \mathrm{~m}$ of flow depth for Sendai and Ishinomaki plains (Namegaya and Satake 2014). By applying this relation, the slip amount of $21 \mathrm{~m}$ on subfault $2^{\prime}$ is needed to explain the tsunami deposit distributions. However, long tsunami inundation distances in flat plains due to M9 class earthquake, studied by Namegaya and Satake (2014), are different from the tsunami inundation in this study. Using the sediment transport simulation, Gusman et al. (2012) showed that the sediment transports were strongly influenced by the tsunami wavelength and topographic condition. Therefore, we decided not to use the relation in our study, and we assumed that a flow depth of more than $0 \mathrm{~m}$ should be needed at the location where the tsunami deposit was found. As a result, the slip amount of $18 \mathrm{~m}$ on subfault $2^{\prime}$ was estimated to explain the tsunami deposit distributions. With this assumption, in all five sites, the computed tsunami inundation area exceeded the inland limit of tsunami deposit distribution. Because the threshold value of $0 \mathrm{~m}$ was chosen, the estimated slip amount and calculated seismic moment of the earthquake should be considered as the minimum value for the earthquake.

Great earthquakes of M7 and M8 class have been repeatedly occurred from off the northern part of Hokkaido to Tohoku region in the Japan Sea. The estimated fault model for the 12th century earthquake is located between the focal regions of the 1993 Hokkaido Nansei-oki earthquake and the 1983 Japan Sea earthquake (Fig. 4). The northern edge of the fault model of the 12th century earthquake is near the southern edge of the fault model of the 1993 Hokkaido Nansei-oki earthquake. The southern edge of the fault model for the 12th century event is uncertain. This is because the tsunami deposit distributions are not sufficient to discuss the length of the southern subfault. However, the estimated fault area of the 12th century earthquake in this study was not ruptured by the 1983 Japan Sea earthquake. Future large

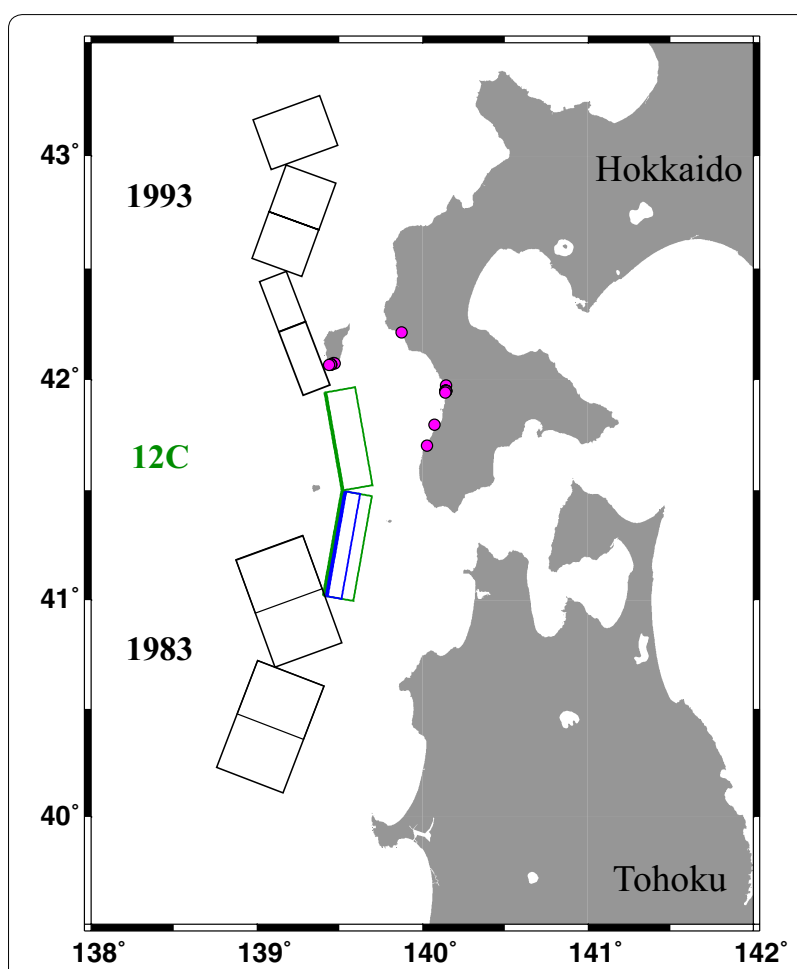

Fig. 4 Fault models of earthquakes that have occurred in southwestern Hokkaido in the Japan Sea: fault model of the 1993 Hokkaido Nansei-oki earthquake estimated by Tanioka et al. (1995), fault model of the 12th century earthquake estimated in this study, and fault model of the 1983 Japan Sea earthquake estimated by Satake (1989). Tsunami deposit distributions are shown in pink circles

earthquake can be expected to re-rupture the estimated fault area of the 12th century earthquake because the average recurrence interval has passed since the latest rupture in the 12th century.

\section{Conclusions}

A fault model of the 12th century southwestern Hokkaido earthquake in the Japan Sea was estimated from tsunami deposit distributions. Numerical simulation of the tsunami was performed to compare computed tsunami inundation areas and tsunami deposit distributions along the coast of Okushiri Island and the Hiyama region in southwestern Hokkaido. A length of $50 \mathrm{~km}$ 
and a slip amount of $18 \mathrm{~m}$ in the northern subfault can well explain the tsunami deposit distributions. The seismic moment of the estimated fault model was calculated to be $9.95 \times 10^{20} \mathrm{Nm}\left(\mathrm{M}_{\mathrm{w}}\right.$ 7.9). This value is larger than those for the other known Japan Sea earthquakes. The estimated fault model of the 12th century earthquake was located between the 1993 Hokkaido Nansei-oki earthquake and 1983 Japan Sea earthquake.

\section{Acknowledgements}

We thank Tatsuhiko Saito, Masato Furuya, Aditya R. Gusman, and an anonymous reviewer for constructive comments. We thank Masanobu Shishikura and Yuichi Namegaya for discussion and helpful comments. We thank Atsushi Urabe, Yasuhiro Takashimizu, and Kazuomi Hirakawa for their discussions and suggestions. We also thank Jun Tajika, Tsumoru Sagayama, Tatsuya Watanabe, Satoshi Ishimaru, Hiromichi Koyasu, Ken'ichi Koshimizu, Hiroshi Fukami, Sunao Ohtsu, and Noritoshi Okazaki for their assisstance.

\section{Authors' contributions}

Kl performed the numerical simulation and drafted the manuscript. YT and GK were major contributors in performing this study and writing the manuscript. $\mathrm{YK}, \mathrm{KN}, \mathrm{WH}, \mathrm{KH}$, and RT performed tsunami deposit study and were contributors in this study. All authors read and approved the final manuscript.

\section{Funding}

This study was carried out under a Priority Research Project of the Hokkaido Research Organization. This study was also supported by MEXT/JSPS KAKENHI Grant Number JP15H05133.

\section{Availability of data and materials}

Bathymetric data are based on M7000 series bathymetric digital data published by the Japan Hydrographic Association, J-EGG500 JODC-Expert Grid data for Geography published by the Japan Oceanographic Data Center, and JTOPO30 published by the Marine Information Research Center, Japan Hydrographic Association. Topographic data are based on digital elevation model of $10 \mathrm{~m}$ mesh published by the Geospatial Information Authority of Japan.

\section{Competing interests}

The authors declare that they have no competing interests.

\section{Author details}

${ }^{1}$ Geological Survey of Japan, National Institute of Advanced Industrial Science and Technology, 1-1-1 Higashi, Tsukuba 305-8567, Japan. ${ }^{2}$ Institute of Seismology and Volcanology, Hokkaido University, N10 W8 kita-ku, Sapporo 060-0810, Japan. ${ }^{3}$ Geological Survey of Hokkaido, Hokkaido Research Organization, N19W12 kita-ku, Sapporo 060-0819, Japan.

Received: 12 February 2019 Accepted: 10 May 2019

Published online: 21 May 2019

\section{References}

Amemiya K, Miyasaka S, Katoh T (1998) Age and depositional landform of Kamuiyama debris avalanche. In: The 105th annual meeting of the geological society of Japan, Abstract, 372. Okushiri Island, Hokkaido

Geological Survey of Hokkaido (2015) Geological records of tsunamis along the coasts of Japan Sea and the Okhotsk Sea in Hokkaido, Japan. In: Special report of geological survey of Hokkaido, No. 42 (in Japanese)

Goto C, Ogawa Y, Shuto N, Imamura F (1997) Numerical method of tsunami simulation with the leap-flog scheme. In: IUGG/IOC TIME project, IOC manual and guides, UNESCO, vol 35, pp 1-126

Gusman AR, Tanioka Y, Takahashi T (2012) Numerical experiment and a case study of sediment transport simulation of the 2004 Indian Ocean tsunami in Lhok Nga, Banda Aceh, Indonesia. Earth Planets Space 64:817-827. https://doi.org/10.5047/eps.2011.10.009

Hata H, Yamamoto M, Nakayama A, Takeuchi T, Yamamoto J (1995) Hydraulic phenomena and tsunami damages in fishing ports-a case study of the Nihonkai-Chubu earthquake tsunami. In: Tsuchiya Y, Shuto N (eds) Tsunami: progress in prediction, disaster prevention and warning. pp 235-248

Hatori T (1983) The tsunami magnitude and source area of the NihonkaiChubu (the Japan Sea) earthquake in 1983. Bull Earthq Res Inst 58:723-734 (in Japanese with English abstract)

Hatori T (1994) Tsunami magnitude and source area of the southwest off Hokkaido earthquake in 1993. Jisin 2(47):1-9 (in Japanese with English abstract)

Hokkaido Disaster Management Council (2017) Anticipated inundation of tsunami along the coast of the Japan Sea. 3-1 (in Japanese). http://www. pref.hokkaido.lg.jp/sm/ktk/bsb/jisinkazansenmon.htm

Imamura F (1996) Review of tsunami simulation with a finite difference method. In: Yeh H, Liu P, Synolakis C (eds) Long-wave runup models. World Scientific, Singapore, pp 25-42. ISBN 981-02-2909-7

Investigative Commission Related to Great Earthquakes in the Japan Sea (2014) Report of investigative commission related to great earthquakes in the Japan Sea (in Japanese). http://www.mlit.go.jp/river/shinngikai _blog/daikibojishinchousa/

loki K, Tanioka Y, Yanagisawa H, Kawakami G (2019) Numerical simulation of the landslide and tsunami due to the 1741 Oshima-Oshima eruption in Hokkaido, Japan. J Geophys Res. https://doi.org/10.1029/2018jb016166

Kase Y, Nishina K, Kawakami G, Hayashi K, Takashimizu Y, Hirose W, Sagayama T, Takahashi R, Watanabe T, Koshimuzu K, Tajika J, Ohtsu S, Urabe A, Okazaki $\mathrm{N}$, Fukami H, Ishimaru S (2016) Tsunami deposits recognized in Okushiri Island, southwestern Hokkaido, Japan. J Geol Soc Japan 122:587-602 (in Japanese with English abstract)

Katsumata K, Kasahara M, Ichiyanagi M, Kikuchi M, Sen R, Kim C, Ivaschenko A, Tatevossian R (2004) The 27 May 1995 M 7.6 northern Sakhalin earthquake: an earthquake on an uncertain plate boundary. Bull Seism Soc Am 94(1):117-130

Kawakami G, Kase Y, Urabe A, Takashimizu Y, Nishina K (2017a) Tsunamis and possible tsunamigenic deposits along the eastern margin of the Japan Sea. J Geol Soc Japan 123:857-877 (in Japanese with English abstract)

Kawakami G, Nishina K, Kase Y, Tajika J, Hayashi K, Hirose W, Sugayama T, Watanabe T, Ishimaru S, Koshimizu K, Takahashi R, Hirakawa K (2017b) Stratigraphic records of tsunamis along the Japan Sea, southwest Hokkaido, northern Japan. Island Arc 26:e12197. https://doi.org/10.1111/iar.12197

Murotani S, Matsushima S, Azuma T, Irikura K, Kitagawa S (2010) Scaling relations of earthquakes on inland active mega-fault systems. In: Abstract of AGU fall meeting, S51A-1911

Nakajima T, Kanai Y (2000) Sedimentary features of seismoturbidites triggered by the 1983 and older historical earthquakes in the eastern margin of the Japan Sea. Sediment Geol 135:1-19

Namegaya Y, Satake K (2014) Reexamination of the A.D. 869 Jogan earthquake size from tsunami deposit distribution, simulated flow depth, and velocity. Geophys Res Lett 41:2297-2303

Nishimura Y, Miyaji N (1995) Tsunami deposits from the 1993 southwest Hokkaido earthquake and the 1640 Hokkaido Komagatake eruption, northern Japan. Pure appl Geophys 144:719-733

Okada Y (1985) Surface deformation due to shear and tensile faults in a halfspace. Bull Seismol Soc Am 75:1135-1154

Okamura Y (2019) Distribution of active faults in Japan Sea and future issues. Jshin 2(71):185-199 (in Japanese with English abstract)

Okamura Y, Kuramoto S, Satoh M (1998) Active structures and their relation to earthquakes along the eastern margin of the Japan Sea. Bull Geol Surv Jpn 49(1):1-18 (in Japanese with English abstract)

Okamura Y, Satake K, Ikehara K, Takeuchi A, Arai K (2005) Paleoseismology of deep-sea faults based on marine surveys of northern Okushiri ridge in the Japan Sea. J Geophys Res 110:B09105. https://doi.org/10.1029/2004J B003135

Okano HK, Fujioka T, Tanaka A, Takeuchi S, Kuramoto H, Tokuyama WSoh, Kato S (1995) Seismo-induced fissure, liquefaction and other microtopography caused by the Hokkaido Nansei-Oki earthquake of July 12, 1993 at Okushiri Ridge Japan Sea, Japan. JAMSTEC J Deep Sea Res 11:379-394 (in Japanese with English abstract)

Satake K (1985) The mechanism of the 1983 Japan Sea earthquake as inferred from long-period surface waves and tsunamis. Phys Earth Planet Inter $37: 249-260$

Satake K (1989) Inversion of tsunami waveforms for the estimation of heterogeneous fault motion of large submarine earthquakes: the 
1968 Tokachi-oki and 1983 Japan Sea earthquakes. J Geophys Res 94(B5):5627-5636

Satake K (1995) Linear and nonlinear computations of the 1992 Nicaragua earthquake tsunami. Pure appl Geophys 144:455-470

Satake K (2007) Volcanic origin of the 1741 Oshima-Oshima tsunami in the Japan Sea. Earth Planets Space 59:381-390. https://doi.org/10.1186/ BF03352698

Satake K, Tanioka Y (1995) Tsunami generation of the 1993 Hokkaido NanseiOki earthquake. Pure appl Geophys 145:803-821

Sato H, Ishiyama T, Kato N, No T, IshikawaM, Takeda T, Koshiya S, Toyoshima T, Kudo K (2014) Estimation of fault models. In: Report of earthquake and tsunami in the Japan Sea research project, 3.2.5.1. pp 203-216

Shuto N (1995) Tsunami, disasters and defence works in case of the 1993 Hokkaido-Oki earthquake tsunami. In: Tsuchiya Y, Shuto N (eds) Tsunami: progress in prediction, disaster prevention and warning. pp 263-276

Shuto N, Chida K, Imamura F (1995) Generation mechanism of the first wave of the 1983 Nihonkai-Chubu earthquake tsunami. In: Tsuchiya Y, Shuto N (eds) Tsunami: progress in prediction, disaster prevention and warning. pp 37-53

Tajima R, Matsumoto Y, Si H, Irikura K (2013) Comparative study on scaling relations of source parameters for great earthquakes in inland crusts and on subducting plate-boundaries. Zisin 2(66):31-45 (in Japanese with English abstract)
Tanioka Y, Satake K, Ruff L (1995) Total analysis of the 1993 Hokkaido Nanseioki earthquake using seismic wave, tsunami, and geodetic data. Geophys Res Lett 22(1):9-12

Terakawa T, Matsu'ura M (2010) The 3-D tectonic stress fields in and around Japan inverted from centroid moment tensor data of seismic events. Tectonics 29:TC6008. https://doi.org/10.1029/2009tc002626

Tokui Y (1989) Volcanic eruptions and their effects on human activity, in Hokkaido, Japan. Ochanomizu-chiri 30:27-33 (in Japanese)

Tsuji Y, Kato K, Nakayama R, Arakawa K, Satake K (1993) Damage to coastal village due to the 1993 Hokkaido Nansei-oki earthquake tsunami. In: Seismological Society of Japan Fall meeting abstract, vol 2, p 45 (in Japanese)

Watanabe, H. (1998) Comprehensive list of tsunami and damage in Japan. 2, 978-4-13-061113-8 (in Japanese)

Yin J, Jull AJT, Burr GS, Zheng Y (2012) A wiggle-match age for the Millennium eruption of Tianchi Volcano at Changbaishan, Northeastern China. Quat Sci Rev 47:150-159

\section{Publisher's Note}

Springer Nature remains neutral with regard to jurisdictional claims in published maps and institutional affiliations

\section{Submit your manuscript to a SpringerOpen ${ }^{\circ}$ journal and benefit from:}

- Convenient online submission

- Rigorous peer review

- Open access: articles freely available online

- High visibility within the field

- Retaining the copyright to your article

Submit your next manuscript at $\boldsymbol{\nabla}$ springeropen.com 